\title{
Effect of temperature on growth, survival and respiratory rate of larval allis shad Alosa alosa
}

\author{
M. Hundt ${ }^{(1), \star}$, M. Schiffer (2),(3), M. Weiss ${ }^{(2)}$, B. Schreiber ${ }^{(1)}$, C.M. Kreiss ${ }^{(3)}$, \\ R. Schulz(1), R. Gergs ${ }^{(1),(4)}$
}

Received June 1, 2015

Revised September 24, 2015

Accepted September 27, 2015

Key-words: endangered species, Alosa alosa, climate change, Gironde

\section{ABSTRACT}

Prior species distribution models identified temperature as one of the most important environmental variables defining the present and future distribution of anadromous allis shad (Alosa alosa). The current study analysed effects of temperature on the recruitment-potential of allis shad by investigating growth and survival at $16,20,24$ and $28{ }^{\circ} \mathrm{C}$ during a ten day rearing trial and by measuring mass-specific respiration. Highest growth in length was at $28{ }^{\circ} \mathrm{C}$; growth at $16{ }^{\circ} \mathrm{C}$ was minimal. At the end of the rearing-period, no significant differences in survival between tested rearing-temperatures were found. Exposure to temperatures of 13 to $30^{\circ} \mathrm{C}$ and subsequent measurement of mass-specific respiration revealed tolerance of temperatures up to $30^{\circ} \mathrm{C}$ and a lower temperature limitation close to $16^{\circ} \mathrm{C}$. After acclimatization of larvae to temperatures ranging from $16-28{ }^{\circ} \mathrm{C}$ for 10 days, $Q_{10}$-values of mass-specific respiration indicated a high adaptive capacity to increasing temperatures, but also the ability to adapt to temperatures as low as $16^{\circ} \mathrm{C}$. Our results indicate that the predicted temperature sensitivity of $A$. alosa cannot be explained by a direct physiological relationship. The obtained results can help to improve predictive modelling and the conservation of allis shad throughout its current distribution range.

\section{RÉSUMÉ}

Effet de la température sur la croissance, la survie et le coefficient respiratoire des larves de grande alose Alosa alosa

Mots-clés : espèce menacée, Alosa alosa,
Les populations de la grande alose anadrome Alosa alosa sont en déclin dans toute l'Europe. Des modèles de distribution des espèces ont identifié la température comme l'une des variables environnementales les plus importantes définissant la distribution géographique actuelle et future d'A. alosa. La présente étude a analysé l'effet de la température sur le potentiel de recrutement de la grande alose en étudiant la croissance et la survie à $16,20,24$ et $28^{\circ} \mathrm{C}$ au cours d'une

(1) Institute for Environmental Sciences, University Koblenz-Landau, Landau, Germany

(2) Department of Marine Aquaculture for Sustainable Fishery, IMARE Institute for Marine Resources, Bremerhaven, Germany

(3) Department of Integrative Ecophysiology, Alfred Wegener Institute, Helmholtz Center for Polar and Marine Research, Bremerhaven, Germany

(4) Federal Environment Agency, Berlin, Germany

* Corresponding author: Hundt@uni-landau.de 
changement climatique, Gironde expérimentation de dix jours et en mesurant la respiration masse-spécifique. À $28{ }^{\circ} \mathrm{C}$ la croissance en longueur d'A. alosa était la plus forte; la croissance à $16^{\circ} \mathrm{C}$ a été la plus faible. À la fin de la période d'élevage, aucune différence significative de la survie aux différentes températures d'élevage n'a été trouvée. Les mesures de la respiration masse-spécifique des larves 1 jour après l'éclosion à 16 à $30^{\circ} \mathrm{C}$ a révélé une tolérance à la température allant jusqu'à $30^{\circ} \mathrm{C}$ et une limitation à une température inférieure proche de $16^{\circ} \mathrm{C}$. Après acclimatation à différentes températures pendant 10 jours, les valeurs $Q_{10}$ de la respiration masse-spécifique ont indiqué une forte capacité d'adaptation à la hausse des températures, mais aussi la capacité à s'adapter à des températures aussi basses que $16^{\circ} \mathrm{C}$. Nos résultats indiquent que $A$. alosa peut être considérée comme une espèce hautement thermo-tolérante, comparable à la plupart des espèces thermophiles des systèmes fluviaux européens; par conséquent, la sensibilité à la température prédite d'A. alosa ne peut pas être expliquée par une relation physiologique directe, mais doit être interprétée dans un contexte écologique plus large. Les résultats obtenus peuvent aider à améliorer la modélisation prédictive de la composition des espèces des rivières européennes et la conservation de la grande alose dans toute son aire de répartition actuelle.

\section{INTRODUCTION}

Since the beginning of the 20th century, anadromous fish have dramatically declined in abundance worldwide, and several populations have been exterminated. This has mainly been attributed to river fragmentation, water quality degradation and destruction of spawning grounds (Jonsson et al., 1999; McDowall, 1999; De Groot, 2002; Bagliniere et al., 2003; Limburg and Waldman, 2009).

One anadromous fish species that has become extinct in many freshwater systems, including the Rhine, is the clupeid allis shad Alosa alosa; the species is included in Appendix III of the Bern Convention and Annexes II and V of the EU Habitats Directive (De Groot, 1990; Aprahamian et al., 2003). A. alosa spawns in the middle to upper reaches of European river systems. Juvenile fish migrate to sea within their first year; males return to freshwater for spawning at the age of four years on average, while their female conspecifics attain sexual maturity approximately one year later at the age of five years (Bagliniere et al., 2003). Although selfsustaining populations of allis shad are currently found only in France and Portugal (Bagliniere et al., 2003), the species is classified as of "least concern" on the Red List of the International Union for the Conservation of Nature (Freyhof and Brooks, 2011). However, this classification is the subject of debate as the species is regarded as vulnerable by the French committee of the IUCN (Rougier et al., 2012) and is classified as endangered on the portugese red list of species (Rogado et al., 2005).

Until the end of the 20th century, the allis shad population in the Gironde-Garonne-Dordogne river system was the largest in Europe, accounting for over 250000 estimated spawners (Rougier et al., 2012). Despite various conservation efforts, such as the construction of a fish lift designed for allis shad (Larinier and Travade, 2002) and the protection of active spawning sites in the Garonne and Dordogne rivers, the population reached its all-time low in 2012 and 2013 (Andreas Scharbert, LIFE+ project "Conservation and restoration of allis shad in the Gironde and Rhine watersheds", personal communication). The reasons for the decline are not well understood, but one possible cause is environmental changes that could have led to recruitment failure in the freshwater phase of this species (Rougier et al., 2012). According to Lassalle et al. (2008), differences between the historical, current and future distribution of $A$. alosa can be best explained by the climate variable temperature. Based on predictive species distribution models, these authors predict a northward shift of the $A$. alosas distribution range and the loss of many basins suitable for allis shad by 2100 owing to suboptimal temperature regimes of warming rivers. 
Temperature is one of the most important abiotic factors controlling the dynamics of larval assemblages of freshwater and marine fish species (Houde and Zastrow, 1993; Jakobsen et al., 2009). Many studies have linked temperature changes to distributional changes of fish stocks, mainly in marine ecosystems (Beare et al., 2004; Alheit et al., 2005; Perry et al., 2005; Pörtner and Peck, 2010) but also in freshwater ecosystems (Hari et al., 2006; Lassalle et al., 2008; Almodovar et al., 2012). However, only few studies have demonstrated temperature sensitivity of individual species based on physiological principles (Pörtner and Peck, 2010). A mechanistic understanding of thermal limitations of ectothermic species is provided by the concept of oxygen- and capacity-limited thermal tolerance (OCLTT concept) developed by Pörtner (2001), which is based on the findings that oxygen supply and the decline of an organism's capacity to perform aerobically (aerobic scope) are the determining factors in thermal tolerance (Pörtner, 2001, 2002) and that performance decrements at suboptimal temperature conditions at high and low temperatures are caused by limits in oxygen supply that derive from insufficient circulatory and ventilatory capacity (Pörtner, 2001, 2002). Furthermore, larval fish are generally considered to be more stenothermal than adults (Rombough, 1988), mainly because of underdeveloped capacities of their central organs (Pörtner et al., 2006). Hence, it can be assumed that any temperature-derived physiological impairment occurs most likely during the early larval phase of $A$. alosa and that later life stages are less sensitive to temperature-induced stress reactions.

This study aims at investigating whether the observed habitat loss of $A$. alosa and its predicted disappearance from several river catchments (Lassalle et al., 2008) can be explained by a low tolerance of allis shad larvae to elevated temperature. The physiological temperature limitations of $A$. alosa were explored by measuring respiration over a range of temperatures encompassing the natural range found in River Garonne during the early larval period of allis shad (Bagliniere et al., 2003; Larnier et al., 2010; Table IV) Furthermore, growth and mortality were measured at four different water temperatures in this range over a period of 10 days.

\section{METHODS}

\section{> ORIGIN AND MAINTENANCE OF FISH LARVAE}

Approximately 20000 fertilized eggs originating from multiple spawners of the Garonne population, were obtained from a specialized egg collection tank according to Clave (2011) at the LIFE allis shad hatchery in Bruch, France. The number of available eggs was limited due to the low number of returning individuals in rivers Garonne and Dordogne in 2012. As no additional eggs were available, all experiments were performed simultaneously.

After incubation in specially designed breeding jars until the eyed egg stage according to Clave (2011), eggs were transported in a salmon egg transportation box to the Eußerthal research facility of the University of Landau (Germany) on 27 May 2012. Eggs were then transferred into individually aerated hatching jars connected to a recirculating aquaculture system (RAS) with a water renewal rate of $200 \% \cdot \mathrm{h}^{-1}$ at $20 \pm 1.5{ }^{\circ} \mathrm{C}$. Eggs were disinfected twice a day for $90 \mathrm{~min}$ in $0.01 \%$ hydrogen peroxide. After hatching, larvae automatically entered a tank (400 L) connected to the same RAS. The temperature was kept constant by a Profilux 3 aquarium computer (GHL GmbH, Germany) supplied with a 3000 W central electric heating system; $\mathrm{pH}$ ranged between 7.3 and 7.6.; Total ammonia nitrogen and nitrite concentrations, measured daily using Visocolor HE kits (Macherey-Nagel GmbH, Germany), were below the detection limit at all times.

\section{> GROWTH AND MORTALITY OF FISH LARVAE}

Immediately after hatching, fish larvae randomly chosen from the $400 \mathrm{~L}$ tank were introduced into 12 gently aerated $5 \mathrm{~L}$ experimental aquaria ( $335 \pm 54$ fish larvae per aquarium) placed 
in temperature-controlled polyethylene tubs. The temperature of the tubs was gradually adjusted from the water temperature of the RAS to the experimental temperature $\left(16 \pm 0.99{ }^{\circ} \mathrm{C}\right.$, $20 \pm 0.99{ }^{\circ} \mathrm{C}, 24 \pm 1.25{ }^{\circ} \mathrm{C}$ and $28 \pm 0.92{ }^{\circ} \mathrm{C}$; three aquaria at each temperature) over $24 \mathrm{~h}$ to allow fish larvae to adapt. Temperature was recorded every 15 min by HOBO Pendant ${ }^{\circledR}$ temperature loggers (Onset Computer Corporation, Bourne MA, USA).

Fish larvae were reared for 10 days at the experimental temperatures with a $13 \mathrm{~h}: 11 \mathrm{~h}$ (day:night) light regime. They were fed ad libitum with Artemia nauplii (Sanders Brine Shrimp Company, Ogden, UT, USA) 12 times a day starting at 2 days post-hatch (dph). Aquaria were cleaned twice a day by exchanging at least $200 \%$ water volume and removing dead larvae and food residuals.

To monitor water quality, total ammonia nitrogen and nitrite concentrations were measured using Visocolor HE kits (Macherey-Nagel GmbH, Germany) every second day. Total ammonia nitrogen never exceeded $0.1 \mathrm{mg} \cdot \mathrm{L}^{-1}$, and nitrite levels always remained below $0.02 \mathrm{mg} \cdot \mathrm{L}^{-1}$. Prior to the experiment, 24 random larvae were collected from the rearing tank; on day 4, 7 and 10, eight fish larvae were removed from each experimental aquarium. The total length of these larvae observed under a stereomicroscope (Motic SMZ 168) equipped with a scale was measured to an accuracy of $0.5 \mathrm{~mm}$. After drying at $60^{\circ} \mathrm{C}$ for $24 \mathrm{~h}$, dry weight was determined to the nearest $0.01 \mathrm{mg}$ using a Sartorius laboratory balance (Mettler-Toledo, Switzerland). During cleaning, dead larvae were counted to calculate survival rate. The survival rate calculation was corrected for fish larvae removed for length and dry weight determination.

\section{>MASS-SPECIFIC RESPIRATION AT DIFFERENT TEMPERATURES}

Between 5 and 10 randomly selected larvae of the same age (1 dph) were transferred from the $20^{\circ} \mathrm{C}$ rearing tank to a heating and cooling, temperature-controlled bath in a $600 \mathrm{~mL}$ glass vessel with approximately $100 \mathrm{~mL}$ of tank water and acclimatized for 20 min to the rearing temperature $\left(13,16,19,21,24,27\right.$ and $30^{\circ} \mathrm{C}$, each $\left.\pm 0.5^{\circ} \mathrm{C}\right)$ to avoid shock reactions and to exclude weak larvae, which died during acclimatization. Temperature was regulated with a Biotherm Pro Aquarium Computer (Dohse Aquaristik GmbH, Germany) connected to a $75 \mathrm{~W}$ heating element (Eheim $\mathrm{GmbH}$, Germany) for heating and a $300 \mathrm{~L} \cdot \mathrm{h}^{-1}$ booster pump (Eheim $\mathrm{GmbH}$, Germany) supplied with tap water for cooling; additionally temperature was manually controlled. For each of three replicates of each temperature, three acclimatized larvae were transferred to a $4 \mathrm{ml} \mathrm{HPLC}$ vial (Sigma-Aldrich, St. Louis, MO, USA) with fully aerated freshwater and placed into the temperature-controlled bath; the control vial for each temperature lacked larvae to correct for bacterial oxygen consumption. Vials were sealed airless with silicone membrane lids. Subsequently, oxygen micro-optodes (needle-type, fibre-optic microsensor, flat broken tip, $140 \mu \mathrm{m}$, Presens Precision Sensing, Regensburg, Germany) precalibrated with fully aerated freshwater (100\% oxygen) and with saturated sodium dithionite $\left(\mathrm{Na}_{2} \mathrm{~S}_{2} \mathrm{O}_{4} ; 0 \%\right.$ oxygen) were inserted into the HPLC vial through the silicone membranes. The micro-optodes were connected to a 4-channel microsensor oxygen meter (Presens Precision Sensing, Germany).

Mass-specific respiration of each of the three replicates at each temperature was measured three times, i.e. nine measurements of a total of 27 Larvae at each temperature were obtained. The oxygen concentration was recorded every $15 \mathrm{~s}$ for at least 20 min or until at least $10 \%$ of the initial oxygen was reduced. To avoid oxygen gradients within the vials, the vials were gently shaken every $5 \mathrm{~min}$. Mass-specific respiration was calculated in $\mu \mathrm{g} \mathrm{O}_{2} \mathrm{mg} \mathrm{DW}^{-1} \cdot \mathrm{h}^{-1}$. The procedure was repeated slightly modified with fish larvae acclimatized for 10 days to four different rearing temperatures $\left(16,20,24,28^{\circ} \mathrm{C}\right)$ and mass-specific respiration was measured at four different exposure temperatures $\left(16,20,24,28^{\circ} \mathrm{C}\right)$; for each temperature, only one larva was transferred to each $2 \mathrm{~mL}$ HPLC vial (Sigma-Aldrich) and the mass-specific respiration was measured nine times with nine larvae per temperature. Because of a defect in the aquarium air supply, the group acclimatized to $20{ }^{\circ} \mathrm{C}$ was lost before the mass-specific respiration was measured. 


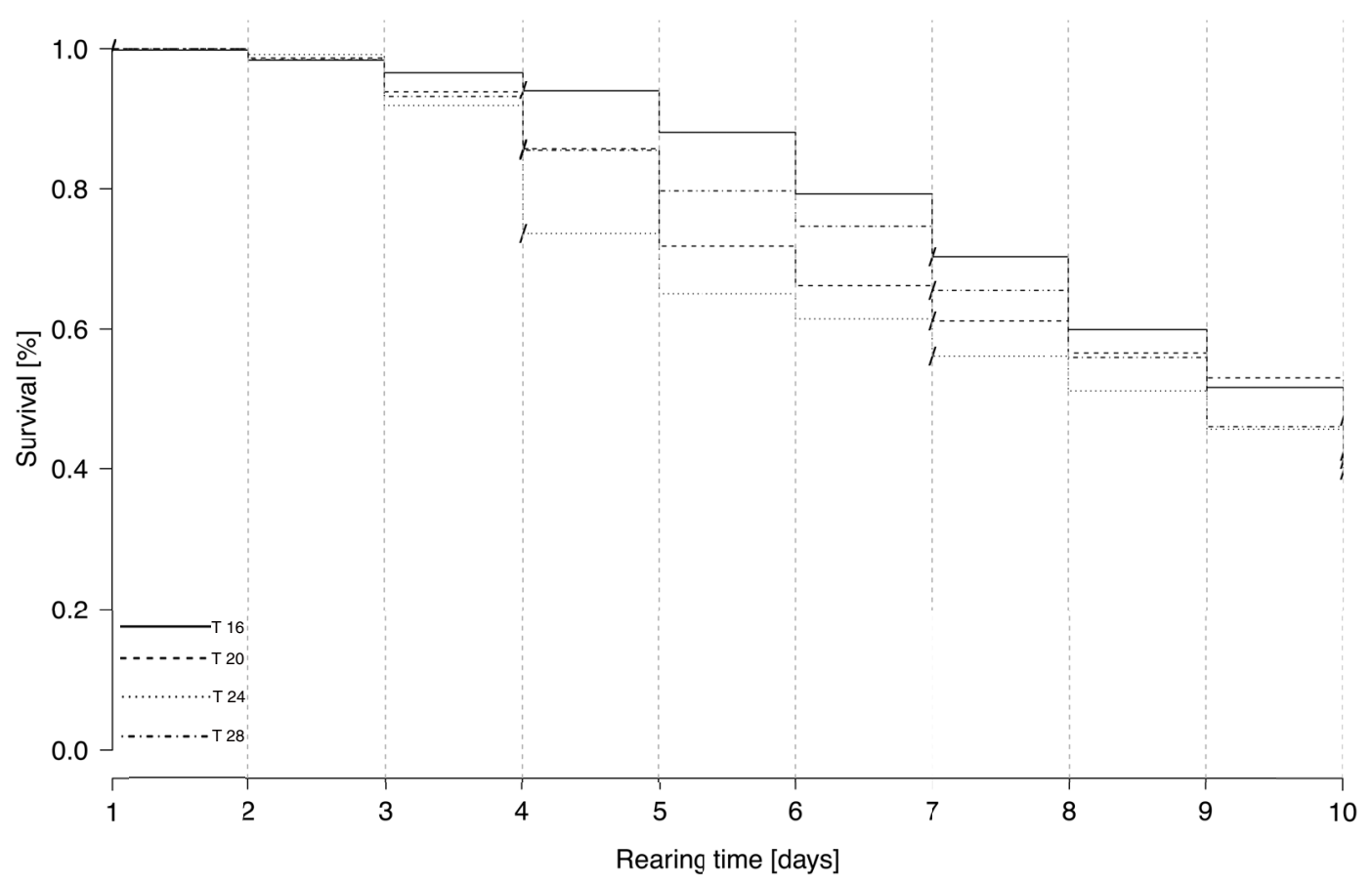

\section{Figure 1}

Relative survival of Alosa alosa larvae during a 10 day rearing period at four different temperatures. No significant differences were detected by cox proportional hazards model.

The mean $Q_{10}$-value as a measure of the increase in metabolic rate was calculated from the mass-specific respiration of the larvae reared at the different temperatures following Crawley (2013).

\section{> STATISTICAL ANALYSES}

All statistical analyses were performed using $R$ (Version 2.13.0) at a significance level of $\alpha=0.05$. The effect of different temperature regimes on survival was analysed by a cox proportional hazards model incorporating temperature as a fixed effect while tank replicate was integrated as a random factor. The effect of temperature regimes on dry weight and length after 10 days was tested using generalized linear modelling (GLM) assuming a Gaussian error distribution. Post-hoc comparison of pairs of treatments was performed on the final day of rearing. Mass-specific respiration of larvae 1 and $11 \mathrm{dph}$ was analysed using GLM assuming a Gaussian error distribution. Prior to analysis, mass-specific respiration data sets were checked for outliers using Nalimov's test (Noack, 1980). Post-hoc comparisons were performed according to the Tukey honest significant differences method (Tukey's HSD post-hoc test). Overdispersion was tested according to Wetherill and Brown (1991).

\section{RESULTS}

\section{> GROWTH AND MORTALITY OF FISH LARVAE}

No significant differences in overall survival of $A$. alosa larvae between the different temperature regimes were detected at the end of the rearing period of 10 days (Figure 1). Overall average survival of fish larvae of all four different temperature regimes was $52.3 \pm 2 \%$ (mean \pm SE). Higher temperatures $\left(20,24\right.$ and $\left.28^{\circ} \mathrm{C}\right)$ tended to result in higher mortality of allis shad larvae at the beginning of the rearing period, while at $16{ }^{\circ} \mathrm{C}$, highest mortality was observed between 5 and 10 days of rearing. 


\section{Table I}

Results of generalized linear models (GLM) comparing length and dry weight of Alosa alosa larvae reared at four different temperatures for 10 days, and of mass-specific respiration (MSR) of larvae at $1 \mathrm{dph}$ (at 16, 19, 21, 24, 27 and $30^{\circ} \mathrm{C}$, each $\pm 0.5^{\circ} \mathrm{C}$ ) and $11 \mathrm{dph}$ (at 16, 20, 24, $28^{\circ} \mathrm{C}$ ).

\begin{tabular}{|c|c|c|c|c|c|c|c|}
\hline \multirow{2}{*}{ Factor } & \multirow{2}{*}{$\begin{array}{c}\text { Error } \\
\text { distribution } \\
\text { Poisson }\end{array}$} & \multirow{2}{*}{$\begin{array}{c}\text { Age of larvae } \\
\text { (dph) }\end{array}$} & \multirow{2}{*}{$\begin{array}{c}\begin{array}{c}\text { Acclimatization } \\
\text { temperature }\end{array} \\
16,20,24,28^{\circ} \mathrm{C} \\
\text { for } 10 \text { days }\end{array}$} & \multicolumn{2}{|c|}{ Residual deviance } & \multicolumn{2}{|c|}{ Null deviance } \\
\hline & & & & 34.9 & $(d f=94)$ & 77.5 & $(d f=95)$ \\
\hline $\begin{array}{l}\text { Dry } \\
\text { weight }\end{array}$ & Poisson & 11 & $\begin{array}{l}16,20,24,28^{\circ} \mathrm{C} \\
\text { for } 10 \text { days }\end{array}$ & 2.2 & $(d f$ & 2.8 & $(d f=90)$ \\
\hline MSR & Poiss & 1 & $20^{\circ} \mathrm{C}$ for $24 \mathrm{~h}$ & 7.2 & $(a$ & 31.5 & $(d f=43)$ \\
\hline MSR & Poisson & 11 & $16^{\circ} \mathrm{C}$ for 10 days & 5. & & 30.9 & $(d f=29)$ \\
\hline MS & Poiss & 1 & $24^{\circ} \mathrm{C}$ for 10 days & 3. & & 8.5 & $(d f=28)$ \\
\hline MSR & Poisson & 11 & $28^{\circ} \mathrm{C}$ for 10 days & 10.4 & $(d f=24)$ & 12.5 & $(d f=27)$ \\
\hline
\end{tabular}
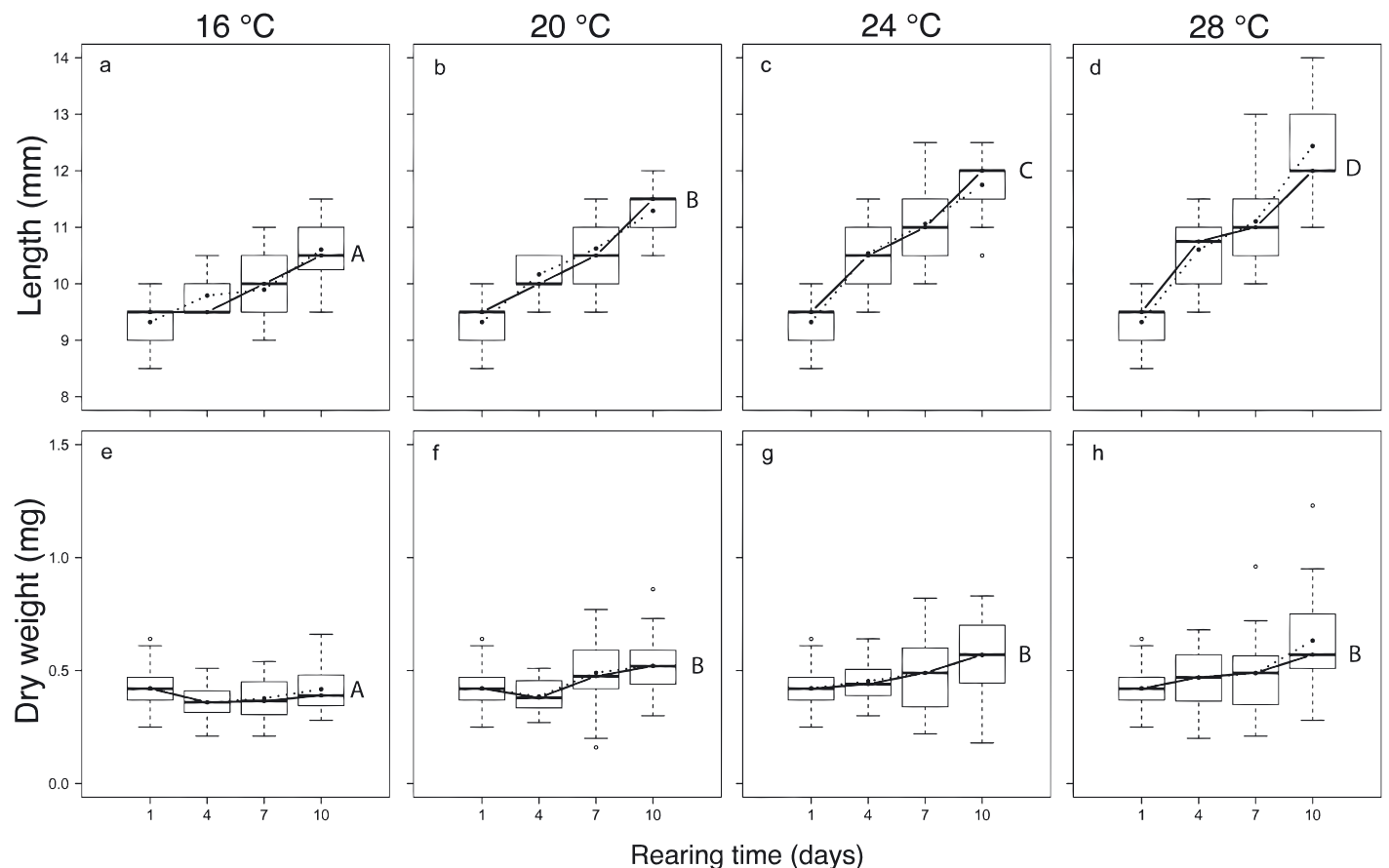

Figure 2

Length and dry weight of Alosa alosa larvae during a 10 day rearing period at four different temperatures. Different capital letters in each boxplot denote significant differences in final mean length or dry weight according to Tukey's HSD at $p<0.05$. The median is indicated by a solid line; the dotted line denotes the mean. Box is the interquartile range; whiskers are maximum and minimum; and dots are outliers.

Significant differences in length were detected in fish larvae acclimatized to the four different rearing temperatures $(p<0.0001$, Table I). Significantly higher final mean length was observed at each consecutive temperature step from 16 to $28^{\circ} \mathrm{C}$ (Figures 2a-2d). The highest final mean length (12.44 $\pm 0.16 \mathrm{~mm}$; mean $\pm \mathrm{SE}$ ) was found at $28^{\circ} \mathrm{C}$ (Figure 2d). Significant differences in weight were detected between the different rearing temperatures $(p<0.001$, Table I). The significantly lowest dry weight increment was detected at a rearing temperature of $16{ }^{\circ} \mathrm{C}$ (Figure $2 \mathrm{e}$ ). No differences in dry weight were found between 20,24 and $28^{\circ} \mathrm{C}$. 


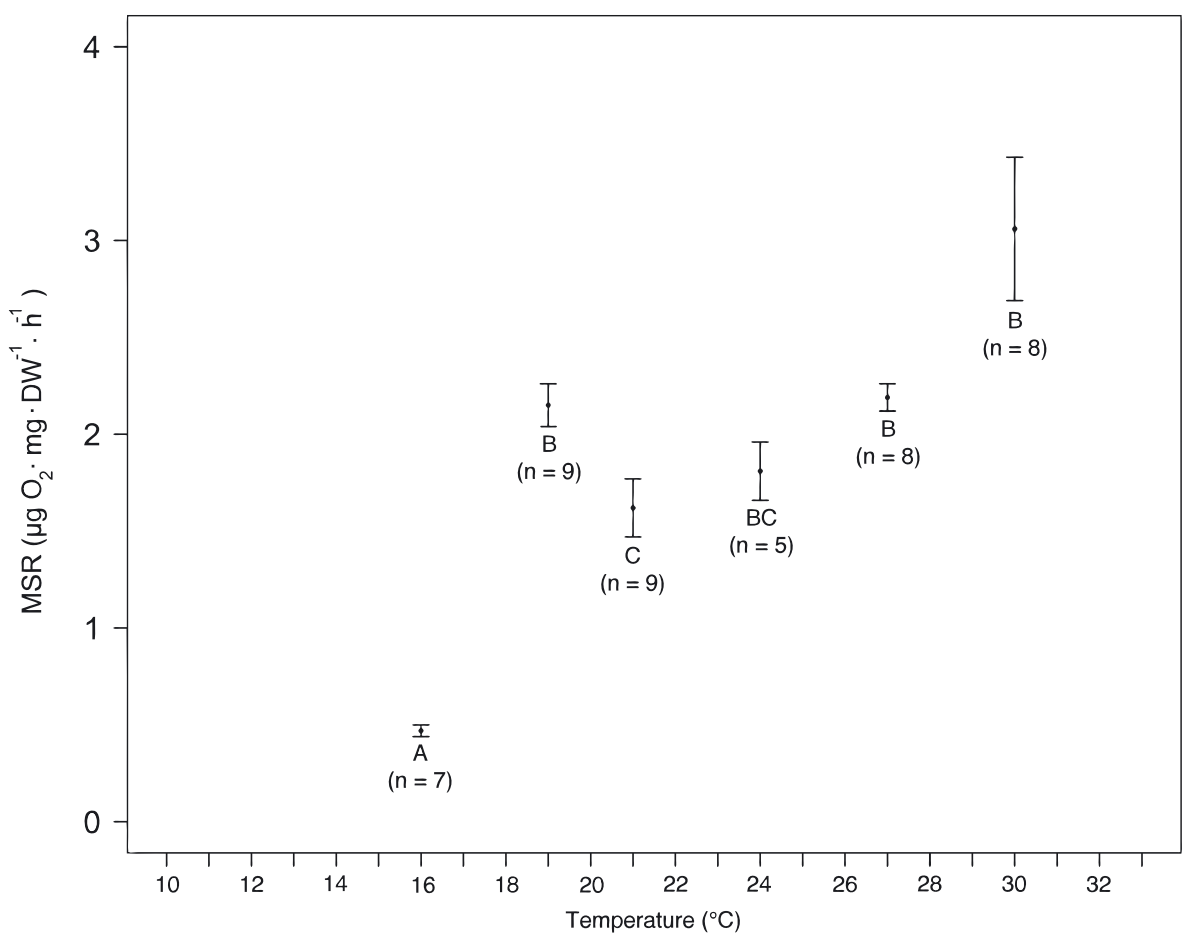

\section{Figure 3}

Mass-specific respiration (MSR) (mean \pm standard error in $\mu \mathrm{g} \cdot \mathrm{O}_{2} \mathrm{mg} \cdot \mathrm{DW} \mathrm{W}^{-1} \cdot \mathrm{h}^{-1}$ ) of Alosa alosa larvae $1 \mathrm{dph}$ at six different temperatures $\left(16,19,21,24,27\right.$ and $\left.30^{\circ} \mathrm{C}\right)$. Different capital letters denote significant differences between temperatures according to Tukey's HSD at $p<0.05$.

\section{Table II}

$Q_{10}$-values of mass specific respiration between six different rearing temperatures of fish larvae acclimatized to $20{ }^{\circ} \mathrm{C}$ for $24 \mathrm{~h}$.

\begin{tabular}{|c|c|c|c|c|c|c|}
\hline Exposure temperature & $16^{\circ} \mathrm{C}$ & $19^{\circ} \mathrm{C}$ & $21^{\circ} \mathrm{C}$ & $24^{\circ} \mathrm{C}$ & $27^{\circ} \mathrm{C}$ & \\
\hline $16^{\circ} \mathrm{C}$ & $x$ & $x$ & $x$ & $x$ & $x$ & $x$ \\
\hline $19^{\circ} \mathrm{C}$ & 15.2 & $x$ & $x$ & $x$ & $x$ & $x$ \\
\hline $21^{\circ} \mathrm{C}$ & 6.9 & 3.8 & $x$ & $x$ & $x$ & $x$ \\
\hline $24^{\circ} \mathrm{C}$ & 4.8 & 1.7 & 3.7 & $x$ & $x$ & $x$ \\
\hline $27^{\circ} \mathrm{C}$ & 4.2 & 1.3 & 2.3 & 4.0 & $x$ & $x$ \\
\hline $30^{\circ} \mathrm{C}$ & 4.7 & 1.3 & 2.1 & 2.8 & 4.7 & $x$ \\
\hline
\end{tabular}

\section{> PHYSIOLOGICAL CAPACITY OF FISH LARVAE 1 DPH}

During acclimatization for mass-specific respiration experiments, all larvae exposed to $13{ }^{\circ} \mathrm{C}$ showed abnormal swimming behaviour and some of them died prior to and during the measurements. As consequence, no mass-specific respiration measurement was possible. Significant differences in mass-specific respiration of $1 \mathrm{dph}$ fish larvae were detected at the remaining exposure temperatures ( $p<0.01$, Table I). Highest mass-specific respiration was found at the highest exposure temperature of $30{ }^{\circ} \mathrm{C}\left(3.06 \pm 0.37 \mu \mathrm{g} \mathrm{O} \cdot \mathrm{mg} \cdot \mathrm{DW}^{-1} \cdot \mathrm{h}^{-1}\right)$ (Figure 3); the lowest was found at $16{ }^{\circ} \mathrm{C}\left(0.47 \pm 0.03 \mu \mathrm{g} \mathrm{O} \cdot \mathrm{mg} \cdot \mathrm{DW}^{-1} \cdot \mathrm{h}^{-1}\right)$ (Figure 3). No significant differences in mass-specific respiration were found between the three highest exposure temperatures of 24,27 and $30^{\circ} \mathrm{C}$, at which significantly higher mass-specific respiration rates were observed than at $16{ }^{\circ} \mathrm{C}$ (Figure 3). Mass specific respiration at $19{ }^{\circ} \mathrm{C}$ was significantly higher than at $21^{\circ} \mathrm{C}$, but not significantly different from $24^{\circ} \mathrm{C}, 27^{\circ} \mathrm{C}$ and $30{ }^{\circ} \mathrm{C}$ (Figure 3).

Corresponding $Q_{10}$-values were found to be highest between the lowest exposure temperature of $16{ }^{\circ} \mathrm{C}$ and the consecutively following warmer exposure temperatures of $19{ }^{\circ} \mathrm{C}$ $\left(Q_{10}=15.2\right)$ and $21^{\circ} \mathrm{C}\left(Q_{10}=6.9\right)$ (Table II). 

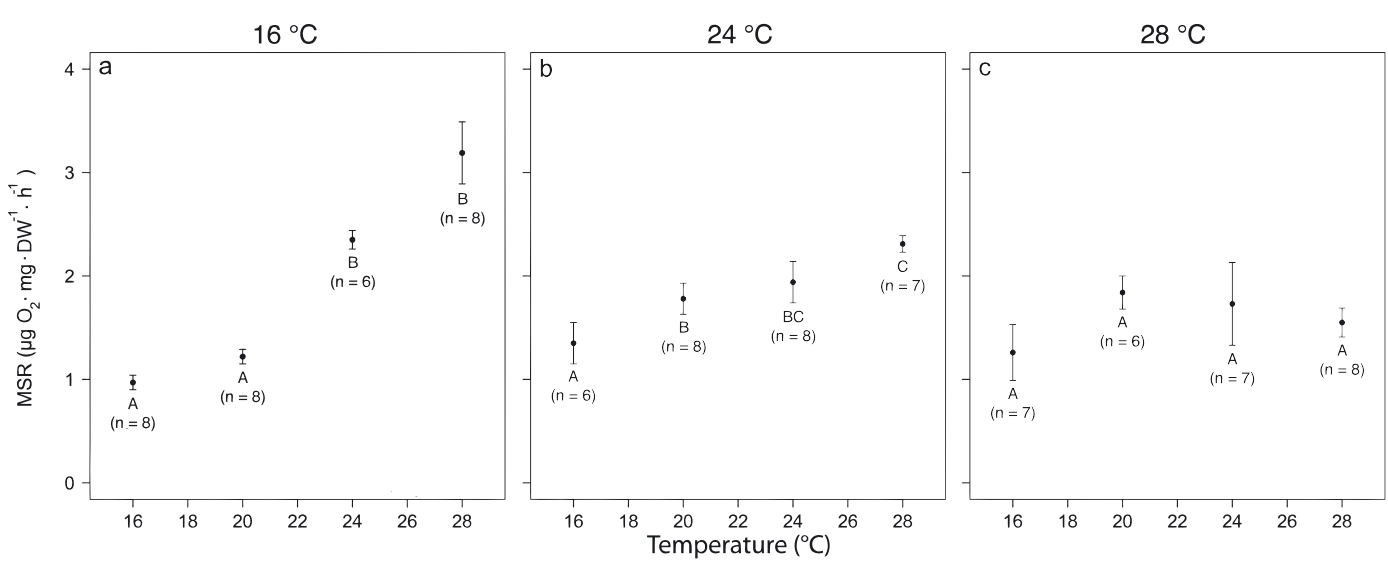

\section{Figure 4}

Mass-specific respiration (MSR) (mean \pm standard error in $\mu \mathrm{g} \cdot \mathrm{O}_{2} \mathrm{mg} \cdot \mathrm{DW}^{-1} \cdot \mathrm{h}^{-1}$ ) of Alosa alosa larvae acclimatized to three different temperatures $\left(16,24\right.$ or $\left.28^{\circ} \mathrm{C}\right)$ over a period of 10 days and then exposed to $16,20,24$ or $28{ }^{\circ} \mathrm{C}$. Different capital letters denote significant differences between temperatures according to Tukey's HSD at $p<0.05$. The number of tested larvae is displayed in parentheses.

\section{Table III}

$Q_{10}$-values of mass specific respiration between four different rearing temperatures of fish larvae acclimatized to 16,24 or $28^{\circ} \mathrm{C}$ for 10 days.

\begin{tabular}{|c|c|c|c|c|c|}
\hline $\begin{array}{l}\text { Acclimatization } \\
\text { temperature }\end{array}$ & $\begin{array}{l}\text { Exposure } \\
\text { temperature }\end{array}$ & $16^{\circ} \mathrm{C}$ & $20^{\circ} \mathrm{C}$ & $24^{\circ} \mathrm{C}$ & $28^{\circ} \mathrm{C}$ \\
\hline \multirow{4}{*}{$16^{\circ} \mathrm{C}$} & $16^{\circ} \mathrm{C}$ & $x$ & $x$ & $x$ & $x$ \\
\hline & $20^{\circ} \mathrm{C}$ & 3.1 & $x$ & $x$ & $x$ \\
\hline & $24^{\circ} \mathrm{C}$ & 3 & 4.8 & $x$ & $x$ \\
\hline & $28^{\circ} \mathrm{C}$ & 2.7 & 3.3 & 3.4 & $x$ \\
\hline \multirow{4}{*}{$24^{\circ} \mathrm{C}$} & $16^{\circ} \mathrm{C}$ & $x$ & $x$ & $x$ & $x$ \\
\hline & $20^{\circ} \mathrm{C}$ & 3.3 & $x$ & $x$ & $x$ \\
\hline & $24^{\circ} \mathrm{C}$ & 1.8 & 2.7 & $x$ & $x$ \\
\hline & $28^{\circ} \mathrm{C}$ & 1.4 & 1.6 & 3 & $x$ \\
\hline \multirow{4}{*}{$28^{\circ} \mathrm{C}$} & $16^{\circ} \mathrm{C}$ & $x$ & $x$ & $x$ & $x$ \\
\hline & $20^{\circ} \mathrm{C}$ & 3.7 & $x$ & $x$ & $x$ \\
\hline & $24^{\circ} \mathrm{C}$ & 1.7 & 2.4 & $x$ & $x$ \\
\hline & $28^{\circ} \mathrm{C}$ & 1 & 1.1 & 2.2 & $x$ \\
\hline
\end{tabular}

\section{> PHYSIOLOGICAL CAPACITY OF ACCLIMATIZED 10 DPH FISH LARVAE}

The mass-specific respiration of fish larvae acclimatized to $16{ }^{\circ} \mathrm{C}$ or $24^{\circ} \mathrm{C}$ and then exposed to $16,20,24$ or $28^{\circ} \mathrm{C}$ significantly differed $(p<0.0001$, Table I). The mass-specific respiration of larvae acclimatized to $16^{\circ} \mathrm{C}$ or $24^{\circ} \mathrm{C}$ gradually increased with exposure temperature; the significantly highest values were found at exposure temperatures of $24{ }^{\circ} \mathrm{C}$ and $28{ }^{\circ} \mathrm{C}$ (Figures $4 \mathrm{a}$ and $4 \mathrm{~b}$ ). In contrast, the mass-specific respiration of fish larvae acclimatized to $28^{\circ} \mathrm{C}$ and exposed to $16,20,24$ or $28^{\circ} \mathrm{C}$ did not significantly differ (Figure 4c). $Q_{10}$-values of mass-specific respiration were generally higher for larvae acclimatized to $16{ }^{\circ} \mathrm{C}$, with the highest value measured at exposure temperatures of 20 and $24{ }^{\circ} \mathrm{C}\left(Q_{10}=4.8\right)$ (Table III). Lowest $Q_{10}$-values were found in fish acclimatized to $28^{\circ} \mathrm{C}$ (Table III).

\section{DISCUSSION}

Growth performance can be considered a useful indicator for determining thermal stress (Pörtner, 2010) because the temperature range in which growth is possible is narrower than 
that allowing survival (Jobling, 1997). Therefore, the highest growth rate of $A$. alosa at $28{ }^{\circ} \mathrm{C}$ (Figure 2), together with no decrease in survival with increasing temperatures ( Figure 1), suggested that such high temperatures lie within the tolerance range of newly hatched $A$. alosa larvae. With regard to growth and survival, the temperature limitations of $A$. alosa are very similar to that of the closely related twaite shad Alosa fallax; larvae of this species also reach their maximal growth performance between 24 and $28^{\circ} \mathrm{C}$ (Navarro et al., 2014). In both species slowest growth was found at the lowest rearing temperature. Similar results were observed in the Aquarium La Rochelle, where temperatures lower than $16{ }^{\circ} \mathrm{C}$ led to slow growth of A. alosa larvae (Pierre Moriniere, Aquarium La Rochelle, personal communication). The obtained lower temperature limits for growth are similar to those of other European thermophilic fish species, such as Abramis brama, which show optimal larval performance at temperatures around $28{ }^{\circ} \mathrm{C}$ (Kucharczyk et al., 1997). Larvae of tench (Tinca tinca), which is among the three most thermo-tolerant native European riverine fish species (Leuven et al., 2011), have the highest growth measured in length at 28 and $31^{\circ} \mathrm{C}$ (Wolnicki and Korwin-Kossakowski, 1993).

Daily growth rate and water temperature limiting growth at low and high critical temperature $\left(T_{\mathrm{c}}\right)$ have a strong interdependence (Pörtner et al., 2001). Low and high critical temperatures of exothermal species reflect the inability of an organism to maintain an aerobic metabolism at these temperatures (Pörtner, 2001, 2002). Our respiratory measurements of $1 \mathrm{dph}$ larvae revealed a high tolerance to the upper measured temperature range; no levelling off in mass-specific respiration was detected at temperatures as high as $30^{\circ} \mathrm{C}$. A levelling in massspecific respiration would indicate insufficient circulatory and ventilatory capacity of larvae to meet tissue oxygen demand (Rombough, 1997; Pörtner, 2001). In contrast, a strong decrease in mass-specific respiration was observed at $16{ }^{\circ} \mathrm{C}$, indicating capacity limitation and the approximation of the critical low temperature threshold below $16{ }^{\circ} \mathrm{C}$. The corresponding high $Q_{10}$-values of mass-specific respiration of 15.2 and 6.9 calculated between $16{ }^{\circ} \mathrm{C}$ and the consecutively following higher exposure temperatures (Table II) were far beyond respiratory $Q_{10}$-values of 2-3, which are characteristic for freshwater fish larvae within their normal temperature range (Rombough, 1988). Values above this range are considered indicative of thermal stress reactions in fish (Crawley, 2013).

After acclimation to $16^{\circ} \mathrm{C}$ for 10 days, $Q_{10}$-values between 16 and $20^{\circ} \mathrm{C}$ of 3.1 were measured (Table III), which indicated some cold acclimation potential of $A$. alosa larvae towards the lower temperature range after this period. Eurythermal fish are able to shift towards lower $T_{c}$ by increasing mitochondrial density according to the given environmental temperature regime (Pörtner et al., 2000). The increase in mitochondrial density during cold acclimation is accompanied by higher energy expenditure due to the maintenance costs of mitochondria (Pörtner et al., 2000).Thus, the expansion of a species temperature range towards lower temperatures is connected to limitations in adapting to higher temperatures. In our study, this was reflected by high mass-specific respiration in larvae acclimatized to $16^{\circ} \mathrm{C}$ and then exposed to temperatures above $20^{\circ} \mathrm{C}$ (Figure $4 \mathrm{a}$ ) and corresponding higher $Q_{10}$-values in this temperature range (Table III). The increased sensitivity of freshly hatched larvae to the lower critical temperature range compared to the sensitivity of larvae $11 \mathrm{dph}$ observed in our study is in accordance with the results of Pörtner and Farrell (2008), who postulated a narrowing of the thermal window within the earliest larval stages.

After acclimatization of the fish larvae to $28{ }^{\circ} \mathrm{C}$ for 10 days, no difference between the massspecific respiration of larvae when exposed to the four different temperatures was detected, which indicated a high warm acclimation capacity of $A$. alosa at this life stage (Figure 4c). Considering that $A$. alosa does not show any spawning activity at temperatures below $16{ }^{\circ} \mathrm{C}$ (Bagliniere et al., 2003), spawning activity in the River Garonne can usually not be observed prior to may. Daily mean water temperature usually increases following the beginning of the spawning period (Table IV), therefore higher capacity of newly hatched larvae to adapt to higher temperatures up to $30{ }^{\circ} \mathrm{C}$ at the expense of a lower temperature limitation close to $16{ }^{\circ} \mathrm{C}$ seems plausible. Daily mean temperatures in spawning stretches of River Garonne exceeding $30{ }^{\circ} \mathrm{C}$ are exceptionally rare and only occurred once in the period between 1993 
Table IV

Minimal (Min), Maximal (Max) and Mean (Mean) average daily temperature regime at Golfech (River Garonne) adjacent to spawning grounds of $A$. alosa.

\begin{tabular}{|c|c|c|c|c|c|c|c|c|c|c|c|c|c|c|}
\hline ear & & $\overline{a n}$ & $\overline{F e b}$ & 1ar & Apr & Vay & une & July & Aug & Sep & Oct & Nov & $\overline{D e c}$ & nnual \\
\hline \multirow{3}{*}{1993} & Min & 4.4 & 5.5 & 5 & 11 & 12.5 & 17.9 & 21 & 20.6 & 14.5 & 10 & 6.2 & 6.3 & 4.4 \\
\hline & Max & .8 & 8.5 & 13.6 & 14.9 & 17.7 & 23.8 & 24.3 & 26.6 & 21.8 & 15.4 & 12.8 & 10 & 26.6 \\
\hline & Mean & 6.5 & 7.5 & 9.7 & 13.0 & 15.6 & 20.7 & 22.8 & 24.6 & 19.6 & 13.5 & 9.6 & 8.5 & 14.3 \\
\hline \multirow{3}{*}{1994} & Min & 5.1 & 6.8 & 10.4 & 8.9 & 13.8 & 16.5 & 20.5 & 23.4 & 15.6 & 12.9 & 10.6 & 5.8 & 5.1 \\
\hline & Max & 9 & 10.2 & $\overline{14}$ & 14.7 & 18.7 & 22.9 & 27.2 & \begin{tabular}{|l|}
27.8 \\
\end{tabular} & 23.9 & 16.7 & 13.2 & 11 & 27.8 \\
\hline & Mean & 7.6 & 7.7 & 11.7 & 11.0 & 16.0 & 19.5 & 25.0 & \begin{tabular}{|l|}
25.6 \\
\end{tabular} & 20.0 & 15.1 & 11.8 & 9.1 & 15.0 \\
\hline \multirow{3}{*}{1995} & Min & 4.3 & 8 & 8 & 10.3 & 13.5 & 15.3 & 22.5 & 22.9 & 16.2 & 15.6 & 9.1 & 6.4 & 4.3 \\
\hline & Max & 8.7 & 10.6 & 11.1 & 15.5 & 19.2 & 23.6 & 27.2 & 27.6 & 22.8 & 18.7 & 16.4 & 9.7 & 27.6 \\
\hline & Mean & 6.5 & 9.3 & 9.7 & 13.2 & 16.3 & 19.3 & 25.3 & 25.6 & 19.4 & 17.4 & 11.5 & 8.3 & 15.2 \\
\hline \multirow{3}{*}{1996} & Min & 8.5 & 5.4 & 7.9 & 10.1 & 13 & 15.3 & 18.7 & 20.3 & 17.1 & 12.7 & 8.1 & 4.6 & 4.6 \\
\hline & Max & 10.2 & 9 & 12.4 & 15 & 19.3 & 24.5 & 26.7 & 25.3 & 21.3 & 17.6 & 13.4 & 10.2 & 26.7 \\
\hline & Mean & 9.3 & 7.2 & 9.7 & 13.2 & 15.8 & 20.8 & 23.3 & 23.6 & 19.3 & 14.7 & 10.7 & 9.0 & 14.7 \\
\hline \multirow{3}{*}{1997} & Min & 4.1 & 7.7 & 10.9 & 13.7 & 15.1 & 18.7 & 18.1 & 22.2 & 21 & 13.4 & 9.7 & 6.5 & 4.1 \\
\hline & Max & 9.9 & 11.2 & 14 & 17.6 & 23.5 & 23.8 & 25.4 & 27.2 & 23.2 & 21.2 & 13.6 & 10 & 27.2 \\
\hline & Mean & 6.8 & 8.9 & 12.7 & 16.1 & 18.7 & 22.0 & 22.3 & 25.5 & 21.9 & 18.3 & 11.3 & 8.2 & 16.1 \\
\hline \multirow{3}{*}{1998} & Min & 5.6 & 6.3 & 9.4 & 10.7 & 12.5 & 17.7 & 22.8 & 21.7 & 17.3 & 13.6 & 5.1 & 4.8 & 4.8 \\
\hline & Max & 9.1 & 9.7 & 13.1 & 15.5 & 19.7 & 23.4 & 25.8 & 26.5 & 23.7 & 19 & 13.7 & 8.5 & 26.5 \\
\hline & Mean & 7.8 & 8.3 & 11.3 & 13.0 & 16.6 & 20.5 & 24.4 & 24.4 & 20.7 & 15.0 & 9.7 & 6.4 & 14.8 \\
\hline \multirow{3}{*}{1999} & Min & 6.3 & 4.4 & 8 & 11.8 & 13.7 & 17.4 & 23.1 & 24.4 & 19.7 & 14.2 & 6.6 & 5.8 & 4.4 \\
\hline & Max & 8.6 & 9.1 & 11.9 & 15.3 & 19.1 & 23 & 25.8 & 25.9 & 25 & 20.2 & 14.8 & 8.1 & 25.9 \\
\hline & Mean & 7.3 & 6.6 & 10.4 & 13.3 & 15.9 & 20.3 & 24.9 & 25.1 & 22.8 & 16.4 & 10.2 & 7.0 & 15.0 \\
\hline \multirow{3}{*}{2000} & Min & 3.9 & 6.2 & 9.4 & 10.3 & 14.5 & 15.1 & 19.7 & 21.6 & 19.7 & 13.2 & 9.6 & 7.3 & 3.9 \\
\hline & Max & 7.9 & 9.8 & 12.2 & 15.6 & 19.1 & 22.6 & 25 & 26.7 & 23.5 & 19 & 14.4 & 11.2 & 26.7 \\
\hline & Mean & 5.8 & 8.3 & 11.0 & 12.9 & 17.4 & 19.7 & 23.0 & \begin{tabular}{|l|}
24.6 \\
\end{tabular} & 21.8 & 15.4 & 11.0 & 9.5 & 15.0 \\
\hline \multirow{3}{*}{2001} & Min & 6.9 & 6.6 & 6.4 & 11.1 & 11.6 & 19 & 20.4 & 23.7 & 18.2 & 15.6 & 7.9 & 1.9 & 1.9 \\
\hline & Max & 8.6 & 9.5 & 14 & 14.6 & 21.2 & 25 & 26 & 27.2 & 25.1 & 19.6 & 15.6 & 9.6 & 27.2 \\
\hline & Mean & 7.9 & 8.3 & 11.4 & 12.7 & 15.6 & 21.5 & 22.9 & 25.2 & 20.3 & 18.0 & 10.4 & 5.4 & 15.0 \\
\hline \multirow{3}{*}{2002} & Min & 4.3 & 7.3 & 8.7 & 11.2 & 12 & 14.5 & 16.3 & 19.5 & 17.2 & 13.6 & $\overline{9}$ & 7.4 & 4.3 \\
\hline & Max & 7.4 & 9.9 & 14.2 & 17.4 & 17.7 & 23.2 & 24.4 & 24.6 & 22.1 & 18.1 & 14 & 9.1 & 24.6 \\
\hline & Mean & 5.5 & 8.4 & 11.7 & 13.8 & 15.2 & 19.2 & 21.6 & \begin{tabular}{|l|}
22.1 \\
\end{tabular} & 20.0 & 15.4 & 11.1 & 8.2 & 14.4 \\
\hline \multirow{3}{*}{2003} & Min & 3.3 & 4.3 & 4.3 & 10.3 & 13 & 17.9 & 22.4 & 25.7 & 17.5 & 10.5 & 9.4 & 5.8 & 3.3 \\
\hline & Max & 8.9 & 8.3 & 11.2 & 16.3 & 17.3 & 25.4 & 27.4 & 30.8 & 25.4 & 20.5 & 12 & 9.7 & 30.8 \\
\hline & Mean & 5.6 & 5.9 & 6.3 & 12.9 & 15.0 & 22.2 & 25.5 & \begin{tabular}{|l|}
28.1 \\
\end{tabular} & 21.1 & 15.7 & 10.9 & 7.8 & 14.8 \\
\hline \multirow{3}{*}{2004} & Min & 4.4 & 5.9 & 5.6 & 10.5 & 11.3 & 16.9 & 20.1 & 23.1 & 18.6 & 14.6 & 7.8 & 6.6 & 4.4 \\
\hline & Max & 9.4 & 7.9 & 11.9 & 14.1 & 17.8 & 23.3 & 26.3 & 27.2 & 24.6 & 20.5 & 14.2 & 8.2 & 27.2 \\
\hline & Mean & 7.0 & 7.0 & 8.6 & 11.7 & 14.6 & 19.9 & 23.4 & \begin{tabular}{|l|}
25.1 \\
\end{tabular} & 22.4 & 18.0 & \begin{tabular}{|l|}
10.1 \\
\end{tabular} & 7.4 & 14.6 \\
\hline \multirow{3}{*}{2005} & Min & 3.1 & 3.3 & 4.2 & 10.8 & 13.6 & 17.5 & 21.6 & 20.9 & 18.2 & 16 & 6.5 & 2.6 & 2.6 \\
\hline & Max & 8.1 & 7.5 & 12.3 & 16.3 & 18.5 & 25.8 & 27.2 & 26.4 & 24.5 & 18.8 & 17 & 7 & 27.2 \\
\hline & Mean & 6.1 & 5.3 & 8.5 & 12.6 & 15.9 & 21.6 & 24.8 & \begin{tabular}{|l|}
23.7 \\
\end{tabular} & 21.0 & 17.0 & \begin{tabular}{|l|l}
11.3 \\
\end{tabular} & 5.0 & 14.4 \\
\hline \multirow{3}{*}{2006} & Min & 3.3 & 4.9 & 6.7 & 12.8 & 15.4 & 19.9 & 25.8 & 21.7 & 18.6 & 15.1 & 11 & 3.3 & 3.3 \\
\hline & Max & 7.1 & 7.9 & 13.4 & 17 & 20.7 & 25.5 & 29 & 27.7 & 26.1 & 19.2 & \begin{tabular}{|l|}
15.7 \\
\end{tabular} & 11.1 & 29 \\
\hline & Mean & 5.7 & 6.3 & 9.6 & 14.6 & 18.1 & 23.5 & 27.6 & \begin{tabular}{|l|}
23.7 \\
\end{tabular} & 21.8 & 17.1 & \begin{tabular}{|l}
13.3 \\
\end{tabular} & 7.5 & 15.7 \\
\hline \multirow{3}{*}{2007} & Min & 3.9 & 4.6 & 8.3 & 10.2 & 13.6 & 15.8 & 20.8 & 21 & 17.7 & 12 & 7.9 & 4.8 & 3.9 \\
\hline & Max & 9.4 & 10.1 & 12 & 17.7 & 19.7 & 22.5 & 24.5 & 25.7 & 22.7 & 19.6 & 11.7 & 10.1 & 25.7 \\
\hline & Mean & 6.9 & 7.9 & 10.5 & 14.1 & 16.2 & 19.8 & 23.0 & \begin{tabular}{|l}
23.7 \\
\end{tabular} & 21.3 & 16.3 & 9.8 & 7.1 & 14.7 \\
\hline \multirow{3}{*}{2008} & Min & 4.6 & 6.2 & 8.3 & 10.1 & $\overline{14}$ & 14.6 & 20.3 & \begin{tabular}{|l|}
22.2 \\
\end{tabular} & 18.4 & 12.1 & 6.3 & 5.1 & 4.6 \\
\hline & Max & 8.7 & 10.8 & 11.6 & 14.2 & 17.3 & 22.2 & 25.9 & 26.2 & 24.3 & 18 & \begin{tabular}{|l|}
12.4 \\
\end{tabular} & 7.8 & 26.2 \\
\hline & Mean & 7.1 & 7.7 & 9.8 & 12.0 & 16.3 & 17.8 & 22.5 & 24.0 & 20.9 & 16.1 & \begin{tabular}{|l|}
10.1 \\
\end{tabular} & 6.5 & 14.2 \\
\hline
\end{tabular}


Table IV

Continued.

\begin{tabular}{|c|c|c|c|c|c|c|c|c|c|c|c|c|c|c|}
\hline Year & & Jan & Feb & Mar & $\overline{A p r}$ & May & June & July & Aug & Sep & Oct & Nov & $\overline{D e c}$ & annual \\
\hline \multirow{3}{*}{2009} & Min & 3.4 & 4.8 & 4.7 & 10.2 & 13.1 & 17.4 & 22.1 & 24.4 & 19.2 & 13.6 & 9.9 & 3.5 & 3.4 \\
\hline & Max & 7.4 & 8.7 & 12.2 & 14.8 & 17.8 & 24.4 & 26.8 & 28.9 & 24.4 & 20.4 & 14.8 & 10 & 28.9 \\
\hline & Mean & 4.8 & 6.3 & 9.8 & 11.7 & 14.8 & 20.0 & 24.7 & 26.0 & 21.8 & 17.2 & 11.7 & 7.0 & 14.7 \\
\hline \multirow{3}{*}{2010} & Min & 1.6 & 1 & 5.7 & 11.5 & 10.2 & 15.6 & 22.2 & 18.6 & 17.5 & 11.5 & 6.7 & 4.5 & 1 \\
\hline & Max & 7.4 & 8.7 & 13 & 17.7 & 18.9 & 22.6 & 26.7 & 28.4 & 23.7 & 18.8 & 12.2 & 7 & 28.4 \\
\hline & Mean & 5.2 & 5.5 & 9.2 & 14.2 & 14.8 & 18.4 & 24.3 & 23.6 & 21.3 & 15.2 & 10.3 & 5.3 & 13.9 \\
\hline \multirow{3}{*}{2011} & Min & 3.7 & 4.1 & 6.9 & 12.5 & 17.2 & 17.1 & 18.3 & 21 & 21.1 & 14.2 & 9.1 & 6.4 & 3.7 \\
\hline & Max & 7.7 & 9.2 & 12.4 & 17.5 & 22.4 & 23.6 & 26.1 & 28 & 25.4 & 21.4 & 14.8 & 10.5 & 28 \\
\hline & Mean & 5.7 & 6.9 & 10.0 & 15.4 & 20.0 & 20.1 & 22.3 & 24.3 & 22.9 & 17.7 & 12.2 & 8.7 & 15.5 \\
\hline \multirow{3}{*}{2012} & Min & 5.4 & 0.5 & 8 & 10.4 & 12.9 & 17.7 & 22.5 & 24.5 & 19.1 & 11.7 & 8.8 & 5.5 & 0.5 \\
\hline & Max & 8.6 & 7.5 & 14.8 & 15.4 & 18.8 & 25.8 & 27.5 & 27.9 & 25.6 & 20 & 11.9 & 8.7 & 27.9 \\
\hline & Mean & 7.3 & 3.5 & 10.6 & 12.8 & 15.7 & 21.0 & 24.4 & 26.5 & 22.2 & 17.1 & 10.7 & 7.4 & 14.9 \\
\hline \multirow{3}{*}{2013} & Min & 2.2 & 4.4 & 5.8 & 9.4 & 11.3 & 12.7 & 17.6 & 22.8 & 18.5 & 17 & 5.7 & 5 & 2.2 \\
\hline & Max & 8.3 & 8.7 & 11.7 & 14.5 & 15.7 & 16.7 & 24.6 & 26 & 24.1 & 21.6 & 16.5 & 7.1 & 26 \\
\hline & Mean & 6.2 & 6.6 & 9.2 & 12.0 & 13.3 & 15.3 & 22.0 & 24.5 & 21.0 & 19.7 & 10.8 & 5.9 & 13.9 \\
\hline \multirow{3}{*}{2014} & Min & 4.2 & 6.1 & 7.2 & 11.4 & 13 & 14.9 & 19 & 20.3 & 19.6 & 15.5 & 11.1 & 5.6 & 4.2 \\
\hline & Max & 8.8 & 10 & 11.7 & 14.5 & 17.1 & 22.4 & 24 & 23.9 & 24 & 20.1 & 17.2 & 10.3 & 24 \\
\hline & Mean & 6.9 & 8.1 & 10.0 & 13.3 & 15.1 & 19.1 & 21.5 & 22.1 & 22.5 & 18.3 & 13.4 & 8.0 & 14.9 \\
\hline \multirow{3}{*}{$\begin{array}{l}\text { Inter- } \\
\text { annual }\end{array}$} & $\overline{M i n}$ & 1.6 & 0.5 & 4.2 & 8.9 & $\overline{10.2}$ & 12.7 & 16.3 & 18.6 & 14.5 & 10 & 5.1 & 1.9 & 0.5 \\
\hline & Max & 10.2 & 11.2 & 14.8 & 17.7 & 23.5 & 25.8 & 29 & 30.8 & 26.1 & 21.6 & 17.2 & 11.2 & 30.8 \\
\hline & Mean & 6.6 & 7.2 & 10.1 & 13.2 & 16.0 & 20.1 & 23.7 & 24.6 & 21.2 & 16.6 & 11.0 & 7.4 & 14.8 \\
\hline
\end{tabular}

and 2014 (Table IV). Temperatures falling below $16^{\circ} \mathrm{C}$ after reaching the temperature threshold for spawning $\left(16-18^{\circ} \mathrm{C}\right)$ have been observed frequently within the period between 1993 and 2014 (Table IV) and therefore might add to larval mortality within River Garonne. Elevated temperatures within the early larval phase of $A$. alosa do therefore not seem to play a major role with regard to the collapse of allis shad stocks within the Gironde-Garonne-Dordogne System. This finding is in accordance with results from laboratory experiments on larval allis shad performed by the National Institute for Environmental and Agricultural Science and Research (IRSTEA), which lead to the conclusion that temperatures in River Garonne rarely exceed the upper $T_{c}$ of $A$. alosa and usually occur for very short time spans, while temperatures exceeding the lower $T_{c}$ have higher ecological significance (personal communication $\mathrm{P}$. Jatteau, IRSTEA). Consequently, the postulated sensitivity of $A$. alosa to rising temperatures (Lassalle et al., 2008) cannot be explained by direct physiologic causality and might therefore reflect responses to other factors influenced by elevated temperatures. For example, the incidence of hypoxic periods in the Gironde-Garonne-Dordogne estuary system has been linked to low river discharge and elevated temperatures (Lanoux et al., 2013). Laboratory experiments with 3-month-old allis shad juveniles indicate high sensitivity to hypoxia at temperatures above $25{ }^{\circ} \mathrm{C}$ and total mortality at dissolved oxygen concentrations lower than $2.2 \mathrm{mg} \cdot \mathrm{L}^{-1}$ (Jatteau and Fraty, 2012). Coastal hypoxia has increased globally since the 1960s owing to eutrophication effects of river systems (Zhang et al., 2010). As estuaries play a physiologically and ecologically detrimental role in the life cycle of juvenile allis shad (Lochet et al., 2009), also indirect effects of high temperatures such as hypoxic periods should be evaluated as a multiple stressor scenario to uncover the mechanism of their widespread disappearance from European river systems. Furthermore, it has to be noted that the experienced increases in temperature are unlikely to threaten fish stocks from the perspective of lethal or sub-lethal effects, but rather have to be interpreted in a synecological context (Blaxter, 1992; Pörtner and Peck, 2010). Therefore, it is important to analyse how increasing temperature might affect early life stages of this species in relation to its prey and predators. 
In conclusion, our results may be useful in improving model parameterization and interspecific comparison throughout Europe to predict changes of particular fish communities of specific river catchments. Furthermore, the discovered tolerance to high temperatures can be useful to optimize rearing conditions for the establishment of ex situ populations, which is considered critical for the conservation of this species (Klinger, 2011).

\section{ACKNOWLEDGEMENTS}

We thank Andreas Scharbert of the LIFE+ project "Conservation and restoration of the allis shad in the Gironde and Rhine watersheds" for continuous support throughout our project. Furthermore we would like to thank David Clave and Laurent Carry of MIGADO for the provision of allis shad larvae, as well as for offering temperature data from River Garonne. The research was funded by Struktur and Genehmigungsdirektion Süd of Rhineland-Palatinate, Germany.

\section{REFERENCES}

Alheit J., Möllmann C., Dutz J., Kornilovs G., Loewe P., Mohrholz V. and Wasmund N., 2005. Synchronous ecological regime shifts in the central Baltic and the North Sea in the late 1980s. Ices. J. Mar. Sci., 62, 1205-1215.

Almodovar A., Nicola G.G., Ayllon D. and Elvira B., 2012. Global warming threatens the persistence of Mediterranean brown trout. Glob. Change Biol., 18, 1549-1560.

Aprahamian M.W., Aprahamian C.D., Bagliniere J.L., Sabatie M.R. and Alexandrino P.J., 2003. Alosa alosa and Alosa fallax spp.: literature review and bibliography. Rand technical report W1- 014/TR. Environment Agency, Bristol, UK.

Bagliniere J.L., Sabatie M.R., Rochard E., Alexandrino A. and Aprahamian M.W., 2003. The allis shad Alosa alosa: biology, ecology, range and status of populations. In: Limburg K.E. and Waldmann J.R. (eds.), Biodiversity, status and conservation of the worlds shads, American Fisheries Society, Bethesda, 85-102.

Beare D.J., Burns F., Greig A., Jones E.G., Peach K., Kienzle M., McKenzie E. and Reid D.G., 2004. Long-term increases in prevalence of North Sea fishes having southern biogeographic affinities. Mar. Ecol. Prog. Ser., 284, 269-278.

Blaxter J.H.S., 1992. The effect of temperature on larval fishes. Neth. J. Zool., 42, 336-357.

Clave D., 2011. Manuel Pour L'Elevage de Larves de Grande Alose (in French). Report for the LifeProject LIFE06 NAT/D/000005: The re-introduction of the Allis shad (Alosa alosa) to the Rhine system. MIGADO, Le Passage D’Agen, France.

Crawley N.E., 2013. The global impact of climate change on fish. Dissertation, Brunel University.

De Groot S.J., 1990. The former allis and twaite shad fisheries of the Lower Rhine, the Netherlands. J. Appl. Ichthyol., 6, 252-256.

De Groot S.J., 2002. A review of the past and present status of anadromous fish species in the Netherlands: is restocking the Rhine feasible? Hydrobiologia, 478, 205-218.

Hari R.E., Livingstone D.M., Siber R., Burkardt-Holm P. and Guettinger H., 2006. Consequences of climatic change for water temperature and brown trout populations in Alpine rivers and streams. Glob. Change Biol., 12, 10-26.

Houde E.D., and Zastrow C.E., 1993. Ecosystem- and taxon-specific dynamic and energetics properties of larval fish assemblages. Bull. Mar. Sci., 53, 290-335.

Jakobsen T., Fogarty M.J., Megrey B.A. and Moksness E., 2009. Fish reproductive biology. John Wiley \& Sons, Chichester, United Kingdom.

Jatteau P. and Fraty R., 2012. Étude de la tolérance à l'hypoxie des juvéniles de grande alose (Alosa alosa) (in French). IRSTEA Etude, 146, 1-15.

Jobling M., 1997. Temperature and growth: modulation of growth rate via temperature change. In: Wood C.M. and Mc Donald D.G. (eds.), Global warming Implications for freshwater and marine fish, Cambridge University Press, Cambridge, 225-254. 
Jonsson B., Waples R.S. and Friedland K.D., 1999. Extinction considerations for diadromous fishes. Ices J. Mar. Sci., 56, 405-409.

Klinger H., 2011. Final Report Life project LIFE06 NAT/D//000005 (The re-introduction of Allis shad (Alosa alosa) in the Rhine System) (in German). Landesamt für Natur, Umwelt und Verbraucherschutz in NRW (LANUV), Kirchhundem-Ahlbaum, Germany.

Kucharczyk D., Luczynski M., Kujawa R and Czerkies P., 1997. Effect of temperature on embryonic and larval development of bream (Abramis brama L.). Aquat. Sci., 59, 214-224.

Lanoux A., Etcheber H., Schmidt S., Sottolichio A., Chabaud G., Richard M. and Abril G., 2013. Factors contributing to hypoxia in a highly turbid, macrotidal estuary (the Gironde, France). Environ. Sci.: Process. Impacts, 15, 585-595.

Larinier M. and Travade F., 2002. The design of fishways for shad. Bull. Fr. Pêche Piscic., 346, 135-146.

Larnier K., Roux H., Dartus D. and Croze O, 2010. Water temperature modeling in the Garonne River (France). Knowl. Manag. Aquat. Ecosyst., 398, 04.

Lassalle G., Beguer M., Beaulaton L. and Rochard E., 2008. Diadromous fish conservation plans need to consider global warming issues: An approach using biogeographical models. Biol. Conserv., $141,1105-1118$.

Leuven R., Hendriks A.J., Huijbregts M., Lenders H., Matthews J. and van der Velde G., 2011. Differences in sensitivity of native and exotic fish species to changes in river temperature. Curr. Zool., 57, 852-862.

Limburg K.E. and Waldman J.R., 2009. Dramatic declines in North atlantic diadromous fishes. Bioscience, 59, 955-965.

Lochet A., Boutry S. and Rochard E., 2009. Estuarine phase during seaward migration for allis shad Alosa alosa and twaite shad Alosa fallax future spawners. Ecol. Freshw. Fish, 18, 323-335.

McDowall R.M., 1999. Different kinds of diadromy: different kinds of conservation problems. ICES J. Mar. Sci., 56, 410-413.

Navarro T., Carrapato C. and Ribeiro F., 2014. Effects of temperature, salinity and feeding frequency on growth and mortality of twaite shad (Alosa fallax) larvae. Knowl. Manag. Aquat. Ecosyst., 412, 07.

Noack S.,1980. Statistische Auswertung von Mess-und Versuchsdaten mit Taschenrechner und Tischcomputer (In German). Walter de Gruyter, Berlin, Germany.

Perry A.L., Low P.J., Ellis J.R. and Reynolds J.D., 2005. Climate change and distribution shifts in marine fishes. Science, 308, 1912-1915.

Pörtner H.O., 2001. Climate change and temperature-dependent biogeography: oxygen limitation of thermal tolerance in animals. Naturwissenschaften, 88, 137-146.

Pörtner H.O., 2002. Climate variations and the physiological basis of temperature dependent biogeography: systemic to molecular hierarchy of thermal tolerance in animals. Comp. Biochem. Physiol. A, $132,739-761$

Pörtner H.O., 2010. Oxygen-and capacity-limitation of thermal tolerance: a matrix for integrating climate-related stressor effects in marine ecosystems. J. Exp. Bio., 213, 881-893.

Pörtner H.O. and Farrell A.P., 2000. Ecology, physiology and climate change. Science, 322, 690-692.

Pörtner H.O. and Peck M.A., 2010. Climate change effects on fishes and fisheries: towards a causeand-effect understanding. J. Fish Biol., 77, 1745-1779.

Pörtner H.O., Van Dijk P., Hardewig I. and Sommer A., 2000. Levels of metabolic cold adaptation: tradeoffs in eurythermal and stenothermal ectotherms. In: Davison W., Howard-Williams C. and Broady P. (eds.), Antarctic Ecosystems: models for wider ecological understanding, Caxton Press, Christchurch, New Zealand, 109-122.

Pörtner H.O., Berdal B., Blust R. and Brix O., 2001. Climate induced temperature effects on growth performance, fecundity and recruitment in marine fish: developing a hypothesis for cause and effect relationships. Cont. Shelf Res., 21, 1957-1997.

Pörtner H.O., Bennett A. F., Bozinovic F., Clarke A., Lardies M.A., Lucassen M., Pelster B., Schiemer F. and Stillman J.H., 2006. Tradeoffs in thermal adaptation: the need for a molecular to ecological integration. Physiol. Biochem. Zool., 79, 295-313. 
Rogado L., Alexandrino P., Almeida P.R., Alves J., Bochechas J., Cortes R., Domingos I., Filipe F., Madeira J. and Magalhães F., 2005. Alosa alosa, Sável (in Portuguese). In: Cabral M.J., Almeida J., Almeida P.R., Dellinger T., Ferrand de Almeida N., Oliveira M.E., Palmeirim J.M. Queiroz A.I., Rogado L. and Santos-Reis M. (eds.), Livro Vermelho dos Vertebrados de Portugal, Institudo da Conservação da Natureza, Lisboa, pp. 71-72.

Rombough P.J., 1997. The effects of temperature on embryonic and larval development. In: Wood C.M. and Mc Donald D.G. (eds.), Global warming Implications for freshwater and marine fish, Cambridge University Press, Cambridge, 225-254.

Rombough P.J., 1988. Respiratory gas exchange, aerobic metabolism, and Effects of Hypoxia During Early Life. In: Hoar W.S. and Randall D.J. (eds.), Fish Physiology, Academic Press, San Diego, 59-161.

Rougier T, Lambert P., Drouineau H., Girardin M., Castelnaud G.R., Carry L., Aprahamian M., Rivot E. and Rochard E., 2012. Collapse of allis shad, Alosa alosa, in the Gironde system (southwest France): environmental change, fishing mortality, or Allee effect? Ices J. Mar. Sci., 69, 1802-1811.

Sousa R., Freitas F.E.P., Mota M., Nogueira A.J.A. and Antunes C., 2013. Invasive dynamics of the crayfish Procambarus clarkii (Girard, 1852) in the international section of the River Minho (NW of the Iberian Peninsula). Aquat. Conserv., 23, 656-666.

Wetherill G.B. and Brown D.W., 1991. Statistical Process Control. Chapman and Hall, New York.

Wolnicki J. and Korwin-Kossakowski M., 1993. Survival and growth of larval and juvenile tench, Tinca tinca L., fed different diets under controlled conditions. Aquac. Res., 24, 707-713.

Zhang J., Gilbert D., Gooday A.J., Levin L., Naqvi S., Middelburg J.J., Scranton M., Ekau W., Pena A. and Dewitte B., 2010. Natural and human-induced hypoxia and consequences for coastal areas: synthesis and future development. Biogeosciences, 7, 1443-1467.

Cite this article as: M. Hundt, M. Schiffer, M. Weiss, B. Schreiber, C.M. Kreiss, R. Schulz and R. Gergs, 2015. Effect of temperature on growth, survival and respiratory rate of larval allis shad Alosa alosa. Knowl. Manag. Aquat. Ecosyst. 416, 27. 